\title{
Molecular Diagnostics, Taxonomy, and Phylogeny of the Stem Nematode Ditylenchus dipsaci Species Complex Based on the Sequences of the Internal Transcribed Spacer-rDNA
}

\author{
Sergei A. Subbotin, Mehrdad Madani, Eino Krall, Dieter Sturhan, and Maurice Moens
}

\begin{abstract}
First author: Institute of Parasitology of the Russian Academy of Sciences, Leninskii prospect 33, Moscow, 117071, Russia; second and fifth authors: Crop Protection Department, Agricultural Research Centre, Burg. Van Gansberghelaan 96, 9820 Merelbeke, Belgium: third author: Institute of Zoology and Hydrobiology, University of Tartu, Vanemuise 46, 51014 Tartu, Estonia; and fourth author: formerly Institut für Nematologie und Wirbeltierkunde, Biologische Bundesanstalt, Toppheideweg 88, 48161 Münster, Germany.

Current address of first author: Department of Nematology, University of California, Riverside 92521.
\end{abstract}

Accepted for publication 10 July 2005.

\begin{abstract}
Subbotin, S. A., Madani, M., Krall, E., Sturhan, D., and Moens, M. 2005. Molecular diagnostics, taxonomy, and phylogeny of the stem nematode Ditylenchus dipsaci species complex based on the sequences of the internal transcribed spacer-rDNA. Phytopathology 95:1308-1315.

The stem nematode Ditylenchus dipsaci is of great economic importance worldwide as a parasite of agricultural crops and horticultural plants. The internal transcribed spacer (ITS) of rDNA from 23 populations of the $D$. dipsaci complex from various host plants were amplified and sequenced. Seven previously studied populations were also included in the study. The phylogenetic analysis of the full ITS and ITS2 sequence alignments using minimum evolution, maximum parsimony, and Bayesian inference under the complex model of DNA evolution revealed trees with two main clades: (i) D. dipsaci sensu stricto with diploid chromosome numbers and comprising most isolates from agricultural, ornamental, and

several wild plants, and (ii) Ditylenchus spp. with polyploid chromosome numbers, reproductively isolated from diploid populations, and subdivided into six subclades ("giant race" from Vicia faba, Ditylenchus species parasitizing various Asteraceae, and a Ditylenchus sp. from Plantago maritima). Using the energy minimization approach and comparative sequence analysis, it has been found that the secondary structure of ditylenchid ITS2 is organized in three main domains. The importance of knowledge on the RNA structure for phylogenetic analysis is discussed. Conventional polymerase chain reaction (PCR) and real-time PCR with SYBR green dye I with a species specific primer have been developed for detection and quantification of $D$. dipsaci sensu stricto. Validation tests revealed a rather high correlation between real numbers of fourth-stage juveniles of the stem nematodes in a sample and expected numbers detected by real-time PCR. Problems of accuracy of quantification are discussed.
\end{abstract}

The stem nematode Ditylenchus dipsaci (Kühn, 1857) Filipjev, 1936 is among the phytonematodes of greatest economic significance worldwide and is widely distributed mainly in temperate areas and on the list of quarantine organisms of many countries around the world. More than 500 plant species from over 40 angiosperm families are known as hosts; however, many of the various biological races of this nematode have a limited host range. $D$. dipsaci lives mostly as an endoparasite in aerial parts of plants (stems, leaves, and flowers) but also attacks bulbs, tubers, and rhizomes. Common symptoms of infestation are swelling, distortion, discoloration and stunting of above-ground plant parts, and necrosis of bulbs and tubers. The economic thresholds of $D$. dipsaci are mostly very low and even population densities of only 10 nematodes per $0.5 \mathrm{~kg}$ of soil may lead to significant crop losses (34). Morphological similarities of, in particular, juvenile stages with other nonpathogenic soil-inhabiting Ditylenchus and tylenchid species make the diagnostics of $D$. dipsaci a difficult task even for experts. Besides precise identification of the species (e.g., in quarantine inspections), knowledge of the local biological race is often desirable, such as when crop rotation measures are considered. As a consequence, a quick and reliable method for diagnosis is required.

Among phytonematodes, $D$. dipsaci has the greatest intraspecific variation in host preference, and accordingly has the highest

Corresponding author: S. A. Subbotin; E-mail address: sergei.subbotin@ucr.edu

DOI: 10.1094/PHYTO-95-1308

(C) 2005 The American Phytopathological Society number of synonyms. It was originally described from teasel (Dipsacus fullonum) (18), but subsequently a total of 13 nominal species have been synonymized with $D$. dipsaci and up to 30 biological races have been differentiated, mainly distinguished in host range and mostly named after their principal host plant. Many nematologists consider $D$. dipsaci a collective species or a species complex $(1,22,23,29,36,39,40,42)$. Various attempts have been made to elucidate the taxonomic status of biological races, certain populations or species synonymized with $D$. dipsaci by interbreeding experiments with many biological races and populations of different origin $(5-8,20,23,35,38,52)$ and by chromosome studies, etc. (42). However, the taxonomic problem remained largely unsolved and the taxonomic treatment of $D$. dipsaci unchanged until today.

Since the last decade, different polymerase chain reaction (PCR) techniques and nuclear sequence analyses have been used for identifying many organisms as well as for solving taxonomic problems and the study of phylogeny. The internal transcribed spacers (ITS1 and ITS2) of ribosomal RNA situated between the small nuclear ribosomal subunit (the $18 \mathrm{~S}$ gene) and the large subunit (the $28 \mathrm{~S}$ gene) have been used for this purpose with respect to plant-parasitic nematodes. Using PCR-restriction fragment length polymorphism (RFLP) of the ITS region, Wendt et al. (54) distinguished the giant bean race from normal races of the stem nematode. Recently, the ITS sequences of several $D$. dipsaci populations were published by Leal-Bertioli et al. (24), Powers et al. (31), and Subbotin et al. (44). Although Subbotin et al. (44) revealed significant sequence divergence within the $D$. dipsaci complex and clearly distinguished polyploid races (the giant bean 
race and population from Cirsium setosum) from three diploid populations, phylogenetic relationships between diploid and polyploid populations remained unsolved.

In view of these issues, the objectives of the present study were (i) to estimate the taxonomic boundaries of the stem nematode species using the ITS-rDNA sequence information, (ii) to reveal the phylogenetic relationships between populations and species based on analysis of the ITS-rDNA using a complex model of evolution considering secondary structure of the premature rRNA, and (iii) to develop conventional and real-time PCR with species specific primers for the diagnosis of the agriculturally important 'normal' biological races of the stem nematode $D$. dipsaci sensu stricto. Some preliminary results have recently been published in brief (43).

\section{MATERIALS AND METHODS}

Nematode populations. A total of 30 populations of the D. dipsaci species complex were used for the study (Table 1). Most of the samples came from collections kept by the authors of this paper or were obtained from colleagues over the years and kept as herbarium specimens. The oldest sample from which amplified rDNA was obtained originated from Pilosella caespitosa tissue collected in 1968. Delimiting Ditylenchus species in the present study was made based on analysis of available information on morphometrics, chromosome number, results of crossbreeding tests, ranges of native host plants, and similarity of the ITS-rDNA sequences. Soil-inhabiting nematodes for experiments with real-time PCR were extracted from samples using a standard filter extraction procedure (11).

DNA isolation and conventional PCR amplification of the ITS-rDNA. For each sample, several dozen juveniles or a few adults were transferred into $8 \mu \mathrm{l}$ of double distilled water and $7 \mu \mathrm{l}$ of worm lysis buffer (45) in an Eppendorf tube and crushed with a glass stem using a microhomogenizor Vibro Mixer (Zürich, Switzerland). Three microliters of proteinase K $(600 \mu \mathrm{g} / \mathrm{ml})$ (Promega Benelux, Leiden, The Netherlands) was added. The tubes were incubated at $65^{\circ} \mathrm{C}(1 \mathrm{~h})$ and $95^{\circ} \mathrm{C}(10 \mathrm{~min})$ consecutively. After centrifugation $(1 \mathrm{~min} ; 16,000 \times g), 3 \mu \mathrm{l}$ of the resulting DNA suspension was added to the PCR mixture containing $2.5 \mu \mathrm{l}$ of 10× PCR buffer, $5 \mu \mathrm{l}$ of Q solution (Qiagen, Hilden, Germany), $0.5 \mu \mathrm{l}$ of dNTPs mixture, $1.5 \mu \mathrm{l}$ of each primer $(1.0 \mu \mathrm{M}), 0.2 \mu \mathrm{l}$ of Taq polymerase ( $T a q$ PCR Core Kit, Qiagen), and double distilled water to a final volume of $25 \mu \mathrm{l}$. Two sets of two primers (synthesized by Eurogentec, Merelbeke, Belgium) were used in the PCR analyses to amplify the whole ITS region. The first set was composed of TW81 (5'-GTTTCCGTAGGTGAACCTGC-3') and AB28 (5'-ATATGCTTAAGTTCAGCGGGT-3') as described by Joyce et al. (16); the second used the combination of rDNA1 $\left(5^{\prime}\right.$ TTGATTACGTCCCTGCCCTTT-3') and rDNA2 (5'-TTTCACTCGCCGTTACTAAGG-3') as described by Vrain et al. (51). To amplify the ITS1 or ITS2 of some samples, we used the combination of the primers Dit58Srev (5'-CAGATGTGCCAAAGGATAGA-3') and TW81 or Dit58Sfor (5'-CTCGGTTCATAGATCGATG-3') and AB28, respectively. The DNA amplification was carried out in a PTC-100 Programmable Thermal Controller (MJ Research, Watertown, MA) consisting of $4 \mathrm{~min}$ at $94^{\circ} \mathrm{C}$; 10 cycles of $20 \mathrm{~s}$ at $94^{\circ} \mathrm{C}, 1 \mathrm{~min}$ at $56^{\circ} \mathrm{C}$, and $2 \mathrm{~min}$ at $72^{\circ} \mathrm{C} ; 25$ cycles of $15 \mathrm{~s}$ at $94^{\circ} \mathrm{C}, 45 \mathrm{~s}$ at $57^{\circ} \mathrm{C}$, and $2 \mathrm{~min}$ at $72^{\circ} \mathrm{C}$ and then $10 \mathrm{~min}$ at $72^{\circ} \mathrm{C}$. After DNA amplification, $3 \mu \mathrm{l}$ of the product was run on a $1 \%$ agarose gel. The remainder was stored at $-20^{\circ} \mathrm{C}$ and then used for sequencing.

Sequencing. PCR products were purified using a QIAquick PCR Purification Kit (Qiagen). DNA fragments were directly sequenced in both directions with TW81, AB28, Dit58Srev, or Dit58Sfor primers with BigDye Terminator Cycle Sequencing Kit (Applied Biosystems, Warrington, UK) according to the manufacturer's instructions. The program used for all sequencing reactions was as follows: $94^{\circ} \mathrm{C}$ for $30 \mathrm{~s}, 50^{\circ} \mathrm{C}$ for $30 \mathrm{~s}$, and $60^{\circ} \mathrm{C}$ for $3 \mathrm{~min}, 30 \mathrm{~s}$, repeated for 25 cycles. Sequences were run on an ABI Prism 310 Genetic Analyzer (Applied Biosystems, Foster City, CA).

Sequence alignment and phylogenetic and secondary structure analysis. Original ITS1-5.8S-ITS2 and ITS2 sequences were

TABLE 1. Populations of the Ditylenchus dipsaci complex used in the present study

\begin{tabular}{|c|c|c|c|c|}
\hline Species & Host plant & Origin & GenBank accession no. & Source and/or reference \\
\hline D. dipsaci sensu stricto & Medicago sativa & Münster, Germany & AY574297 & D. Sturhan \\
\hline D. dipsaci sensu stricto & Medicago sativa & Island Hiiumaa, Kassari, Estonia & AF396320 & H. Krall, Subbotin et al. (44) \\
\hline D. dipsaci sensu stricto & Zea mays & Hessen, Germany & AY574294 & D. Sturhan \\
\hline D. dipsaci sensu stricto & Phlox drummondii & Bückeburg, Germany & AY574291 & D. Sturhan \\
\hline D. dipsaci sensu stricto & Allium sativum & São Paulo, Quataquará, Brazil & - & Leal-Bertioli et al. (24) \\
\hline D. dipsaci sensu stricto & Allium sativum & Israel & AY574298 & D. Sturhan \\
\hline D. dipsaci sensu stricto & Beta vulgaris & Münster, Germany & AY574299 & D. Sturhan \\
\hline D. dipsaci sensu stricto & Plantago lanceolata & Wiesbaden, Germany & AY574301 & D. Sturhan \\
\hline D. dipsaci sensu stricto & Trifolium pratense & Viljandi, sample 1, Estonia & AF396319 & H. Krall, Subbotin et al. (44) \\
\hline D. dipsaci sensu stricto & Trifolium pratense & Viljandi, sample 2, Estonia & AY574300 & H. Krall \\
\hline D. dipsaci sensu stricto & Digitalis lutea & Münster, Germany & AY574292 & D. Sturhan \\
\hline D. dipsaci sensu stricto & Avena sativa & Stuttgart, Germany & AY574293 & P. Knuth \\
\hline D. dipsaci sensu stricto & Veronica gentianoides & Münster, Germany & AY574295 & D. Sturhan \\
\hline D. dipsaci sensu stricto & Allium cepa & Münster, Germany & AY574289 & D. Sturhan \\
\hline D. dipsaci sensu stricto & Allium сера & Italy & AY574290 & F. Lamberti \\
\hline D. dipsaci sensu stricto & Lysimachia vulgaris & Münster, Germany & AY574296 & D. Sturhan \\
\hline D. dipsaci sensu stricto & Fragaria sp. & Moscow, Russia & AF396321 & V. Chizhov, Subbotin et al. (44) \\
\hline D. dipsaci sensu stricto & Vicia faba & France & - & Leal-Bertioli et al. (24) \\
\hline Ditylenchus sp. B & Vicia faba & Gharb region, Morocco & AF396323 & S. Amiri, Subbotin et al. (44) \\
\hline Ditylenchus sp. B & Vicia faba & Syria & AY574286 & D. Sturhan \\
\hline Ditylenchus sp. B & Vicia faba & England & AY574284 & D. Sturhan \\
\hline Ditylenchus sp. B & Vicia faba & Erding, Germany & AY574285 & D. Sturhan \\
\hline Ditylenchus sp. C & Cirsium setosum & Moscow region, Russia & AF396322 & V. Chizhov, Subbotin et al. (44) \\
\hline Ditylenchus sp. D & Pilosella caespitosa & Gaidary, Kharkov region, Ukraine & AY574305 & V. Zinovjev \\
\hline Ditylenchus sp. D & Pilosella officinarum & Pesotchin, Kharkov region, Ukraine & AY574304 & Z. Volodchenko \\
\hline Ditylenchus sp. E & Crepis praemorsa & Laelatu, Haapsalu district, Estonia & AY574303 & H. Krall \\
\hline Ditylenchus sp. F & Leontodon autumnalis & Parniku, Estonia & AY574306 & E. Krall \\
\hline Ditylenchus sp. F & Pilosella officinarum & Hirmuste, Estonia & AY574302 & H. Krall \\
\hline Ditylenchus sp. G & Plantago maritima & Altenbruch, Germany & AY574287 & D. Sturhan \\
\hline Ditylenchus sp. G & Plantago maritima & Mellum, Germany & AY574288 & D. Sturhan \\
\hline D. destructor & Solanum tuberosum & Moscow, Russia & AY987007 & V. N. Chizhov \\
\hline
\end{tabular}


obtained from 21 and 2 Ditylenchus populations, respectively. ClustalX 1.64 (48) was used to align the 23 new DNA sequences with seven published sequences of $D$. dipsaci $(24,44)$ and with $D$. destructor as outgroup taxon. Two alignments including either the full ITS (ITS1-5.8S-ITS2) or the ITS2 region were generated. Phylogenetic reconstruction of the full ITS sequence alignment was obtained by minimum evolution (ME) with the HKY85 model of DNA evolution and maximum parsimony (MP) analysis using PAUP* 4b4a (Sinauer Associates, Sunderland, MA) (47). For MP analysis, gaps were coded as missing data and molecular characters were assessed as independent, unordered, and equally weighted. Robustness of the clade was assessed by the bootstrap analysis yielding bootstrap percentage for each node estimated from 1,000 replicates for ME and MP trees. Pairwise divergences between taxa were computed as the absolute distance values and the percent mean distance values based on whole DNA alignment and adjusted for missing data.

A Bayesian interference (BI) analysis of the ITS2 sequence alignment was conducted using MrBayes 3.0 (13). We ran BI under the complex model as implemented in the program: the double model with 16 states of nucleotide doublets for stems and the standard model of substitution with four nucleotide states for loops and bulges. Analyses were initiated with a random starting tree and were run with four chairs for $1.0 \times 10^{6}$ generation and sampling at intervals of 100 generations. After discarding burn-in samples, the remaining samples were used to generate a $50 \%$ majority rule consensus tree.

All the sequences reported here have been deposited in the GenBank database under the accession numbers given in Table 1. Alignments and trees are deposited in the TreeBASE database with accession nos. SN2275 8291 to 8296 .
The secondary structure of the ITS2 premature rRNA of Ditylenchus species was predicted using the energy minimization approach for each sequence as applied in the computer program Mfold version 3 (56). A single consensus structure was manually reconstructed based on the range of optimal and suboptimal structures generated by the Mfold program. Correctness of consensus secondary structure for all ITS2 sequences was verified using comparative sequence analysis (3).

PCR with specific primer. All Ditylenchus species used in this study were considered in the test of the specific primer for diagnostics of $D$. dipsaci sensu stricto. Several putative specific primers were manually designed based on information on the ITS sequences and tested with a universal primer. Only the set composed of the specific DitNF1 primer (5'-TTATGACAAATTCATGGCGG-3') and the universal rDNA2 primer was used for final PCR evaluation. PCR mixtures were prepared as described previously and the PCR program consisted of 4 min at $94^{\circ} \mathrm{C}$; 35 cycles of $15 \mathrm{~s}$ at $94^{\circ} \mathrm{C}, 30 \mathrm{~s}$ at $57^{\circ} \mathrm{C}$, and $30 \mathrm{~s}$ at $72^{\circ} \mathrm{C}$; and $10 \mathrm{~min}$ at $72^{\circ} \mathrm{C}$. The negative control contained the PCR mixture without any DNA template. Seven microliters of each amplified sample was analyzed by electrophoresis in agarose gel. Products visualized with ethidium bromide were photographed under UV light.

Real-time PCR with SYBR green I. Real-time PCR was performed in 96-well optical reaction plates using the automated ABI Prism 7900 HT sequence detector (PE Applied Biosystems, Foster City, CA). Nematode specimens were transferred to an Eppendorf tube with $10 \mu \mathrm{l}$ of double distilled water and crushed with a glass rod powered by a Vibro Mixer. Fifty microliters of $1 \times$ PCR buffer and $5 \mu \mathrm{l}$ of proteinase $\mathrm{K}(600 \mu \mathrm{g} / \mathrm{ml})$ were added to the tube, which was incubated for $2 \mathrm{~h}$ at $65^{\circ} \mathrm{C}$ followed by $10 \mathrm{~min}$

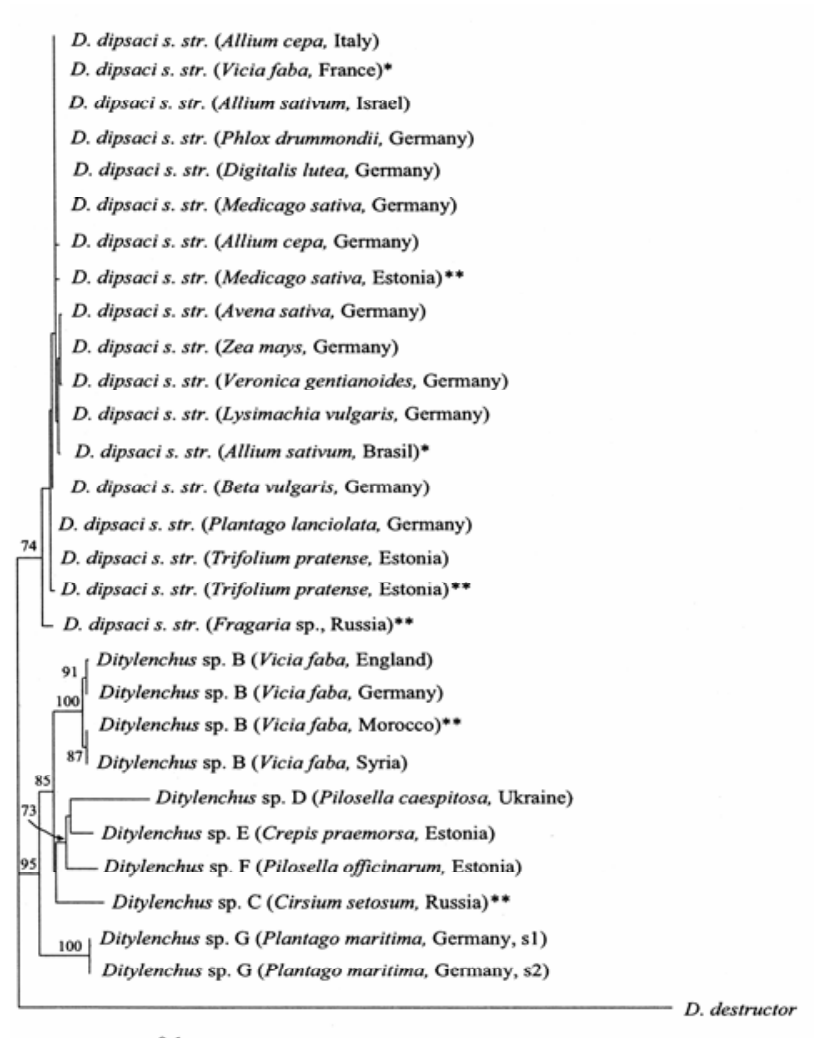

0.1

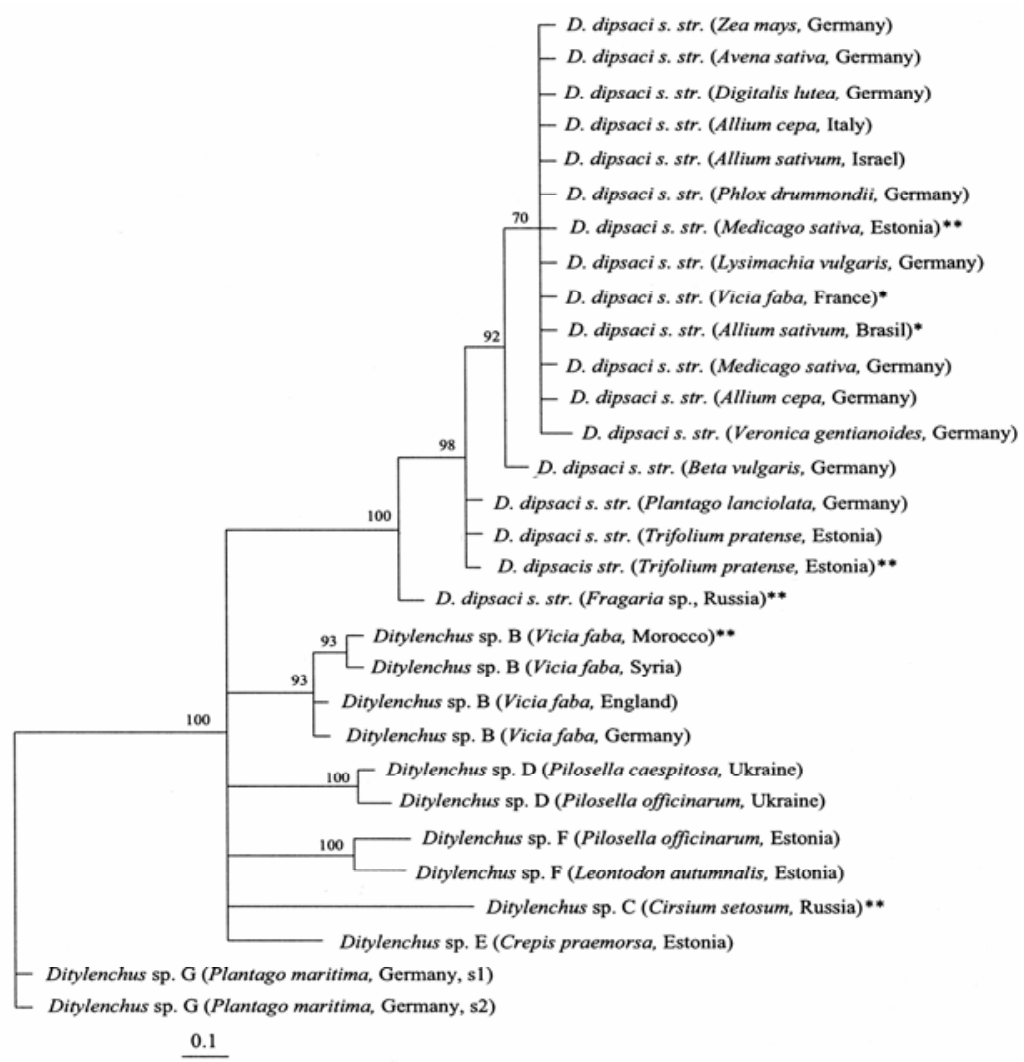

B

Fig. 1. A, Neighbor-joining tree resulting from analysis (HKY85) of the alignments of internal transcribed spacer 1 (ITS1)-5.8S-ITS2 of the Ditylenchus dipsaci species complex and D. destructor. Bootstrap supports more than 50\% are given for appropriate clade. B, The 50\% majority consensus tree inferred from Bayesian analysis of the ITS2 alignment (Ditylenchus sp. G-outgroup) generated from the complex model: GTR+I+G for loops and bulges and 16 doublet models for stems. Posterior probabilities are given on appropriate clades. * Indicates sequences from Leal-Bertioli et al. (24); and ** indicates sequences from Subbotin et al. (44). 
at $95^{\circ} \mathrm{C}$. PCR was performed in a $25-\mu$ l reaction mixture containing $12 \mu \mathrm{l}$ of the SYBR Green PCR Master Mix (PE Applied Biosystems) consisting of dNTPs and Taq polymerase, $1.3 \mu \mathrm{l}$ of each primer $(0.9 \mu \mathrm{M}), 8 \mu \mathrm{l}$ of DNA suspension, and $2.4 \mu \mathrm{l}$ of double distilled water. The species specific primer DitNF1 and the universal primer DitReal-timeR2 (5'-CAGAGTGAAATAGCCAGTCGATTC-3') designed with Primer Express (Applied Biosystems, version 2.0) were used in the reaction. Negative controls without DNA were also run. The manufacturer's recommended universal thermal protocol was used for PCR amplification: 2 min preheating at $50^{\circ} \mathrm{C}$ followed by $10 \mathrm{~min}$ of initial template denaturation and activation of hot start polymerase step at $95^{\circ} \mathrm{C}, 30$ cycles of $95^{\circ} \mathrm{C}$ for $15 \mathrm{~s}$, and a combined annealing/extension phase at $65^{\circ} \mathrm{C}$ for $1 \mathrm{~min}$.

The critical threshold $(\mathrm{Ct})$ value for each PCR was automatically calculated and analyzed by the ABI Prism sequence detection system software. $\mathrm{Ct}$ values were plotted against the logarithm of the number of $D$. dipsaci known from twofold DNA dilution series to produce a standard curve. For calculation of the standard curve, three genomic DNA extractions from 10 specimens of fourth-stage juveniles of the Italian onion population were used. For the validation test, DNA was extracted from samples containing 10, 3, and 1 specimen of fourth-stage juveniles and samples containing three ditylenchid specimens with 10 to 15 soil-inhabiting nematodes in 10 to 20 replicates. DNA melting curve analysis of the resulting amplicon was performed at the end of the amplification by cooling the samples at $1.6^{\circ} \mathrm{C} / \mathrm{s}$ (ramp 100\%) to $60^{\circ} \mathrm{C}$ and then increasing the temperature to $95^{\circ} \mathrm{C}$ at $0.03^{\circ} \mathrm{C} / \mathrm{s}$ (ramp 2\%). The fluorescence emission was measured every $7 \mathrm{~s}$ (each data point collection in $0.2^{\circ} \mathrm{C} / \mathrm{s}$ ) over $20 \mathrm{~min}$.

The specificity of the real-time primer set for the detection of D. dipsaci sensu stricto was tested against all other Ditylenchus species used in this study. Controls without any DNA template and DNA extracted from the mixture of soil-inhabiting nematodes without Ditylenchus spp. were also included in the tests. To verify both the reproducibility and accuracy of DNA extraction and the real-time PCR method, we performed independent runs for samples. Resulting PCR products were also run on the agarose gels.

\section{RESULTS}

Sequence and phylogenetic analyses of the ITS-rDNA. The PCR amplification of the fragment composed of a part of the $18 \mathrm{~S}$ gene, ITS1, 5.8S gene, ITS2, and a part of the 28S gene using the primer combination $\mathrm{AB} 28$ and TW81 or rDNA1 and rDNA2 yielded a single fragment with a length of approximately 760 or $970 \mathrm{bp}$, respectively. The length for the entire ITS region includeing the $5.8 \mathrm{~S}$ gene ranged from 671 to $673 \mathrm{bp}$. ME analysis of the ITS1-5.8S-ITS2 alignments and BI analysis of the ITS2 generated trees with similar topology containing two main clades (Fig. 1): (i) a clade composed of most isolates from cultivated plants and some from ornamental and wild plants belonging to different plant families, which are considered here as members of $D$. dipsaci sensu stricto; and (ii) a clade subdivided into six subclades, the first subclade with populations of the "giant race" from field bean, designated here as Ditylenchus sp. B, four subclades with populations from different Asteraceae genera, designated here as Ditylenchus spp. C, D, E, and F, and a last subclade grouping Ditylenchus sp. G from Plantago maritima. MP analysis generated trees with the same topology but with lower bootstrap values than obtained from ME analysis (data not shown). The pair-wise divergence of the ITS1-5.8S-ITS2 or ITS2 sequences of the $D$. dipsaci complex varied from 0 to $7.6 \%$ (0 to 50 nucleotides) or from 0 to $13.4 \%$ ( 0 to 26 nucleotides), respectively. The divergence of the ITS1-5.8S-ITS2 sequences within the first clade, considered $D$. dipsaci sensu stricto, varied from 0 to $1.3 \%$ (0 to 9 nucleotides) and within the giant race from field bean or Ditylenchus sp. B from 0 to $0.4 \%$ (0 to 3 nucleotides). The di-

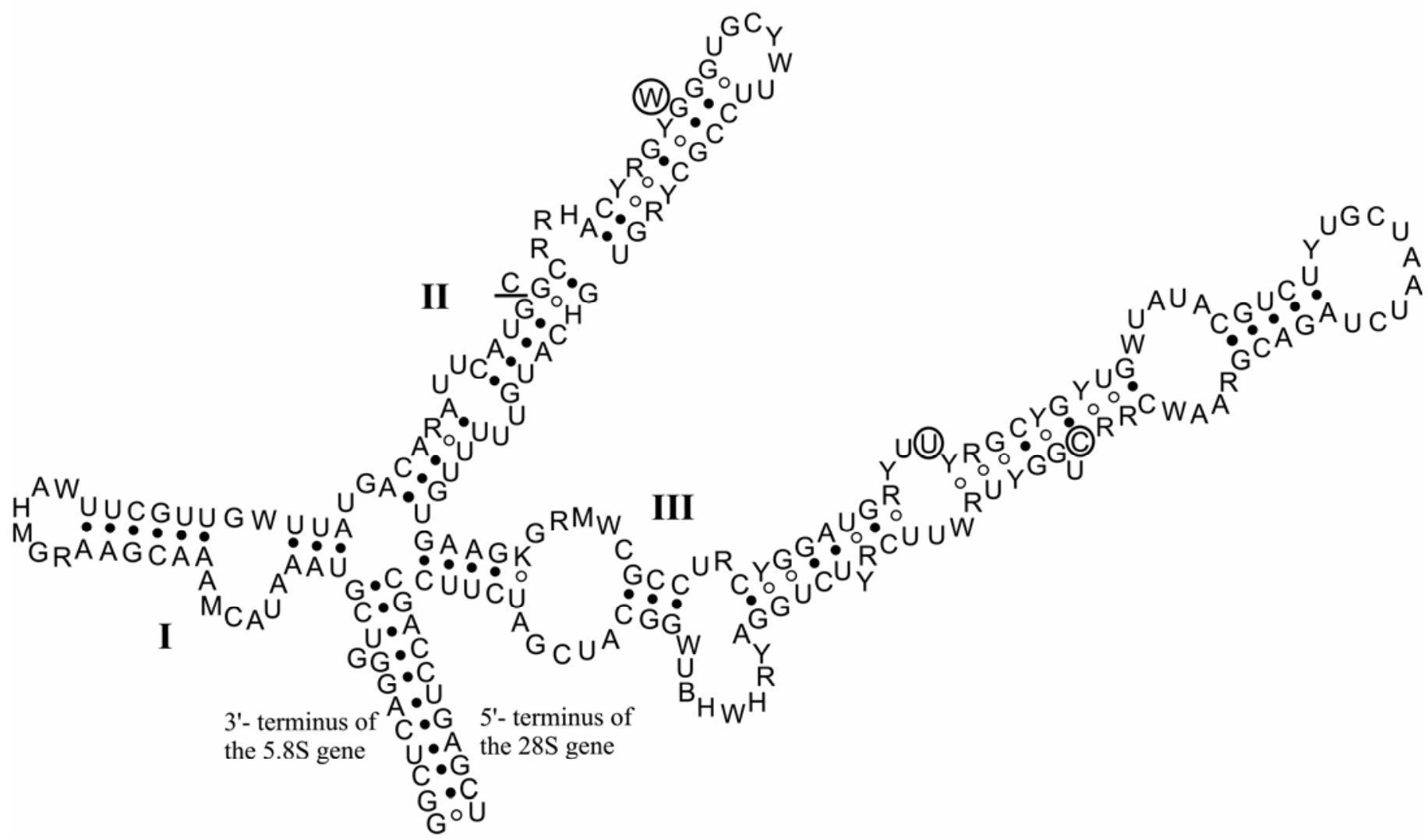

Fig. 2. Consensus putative secondary structure of internal transcribed spacer 2 in the 5.8S-28S premature RNA for the Ditylenchus dipsaci complex. Deletion events are indicated as circles. Additional unpaired nucleotide (perhaps, the result of sequence reading mistake) in sequences published by Leal-Bertioli et al. (24) is underlined. 
vergence of the ITS2 sequences varied for $D$. dipsaci sensu stricto from 0 to $3.1 \%$ (0 to 6 nucleotides); Ditylenchus sp. B, 0 to $0.5 \%$ (0 to 1 nucleotide); Ditylenchus sp. D, 0.5\% (1 nucleotide); Ditylenchus sp. F, 2.0\% (4 nucleotides); and Ditylenchus sp. G, 0\%.

Prediction of secondary structure of the ITS2 region of premature rRNA. Using the energy minimization approach and comparative sequence analysis, it was possible to predict the secondary structure of ditylenchid ITS2 which is organized in three main helices (Fig. 2). The basis of this model is a helix comprising the complementary base pairing of the $3^{\prime}$ terminus of the $5.8 \mathrm{~S}$ gene with the $5^{\prime}$ terminus of the $28 \mathrm{~S}$ gene. At least $60 \%$ of the nucleotides of the ITS2 are involved in base pairing of the three helices. Most base paired positions involved A-U or C-G or less stable G-U combinations. Out of the 48 substitution changes, 31 occurred in the bulges and 17 in the stems; thus, the mutation rate was almost three times higher in the bulges than in the stems. Three deletion events were revealed: (i) unpaired nucleotide in helix II, (ii) uracil in internal bulge of helix III, and (iii) a paired cytosine in the stem of helix III.

PCR with specific primer. Several putative specific primers for $D$. dipsaci sensu stricto were designed and tested. After preliminary examination, only one set composed of the specific primer DitNF1 and the universal primer rDNA2 was chosen and tested with all samples. The expected 263-bp fragment was obtained only with samples containing specimens of $D$. dipsaci sensu stricto (Fig. 3). No positive reactions were observed with other Ditylenchus species (Fig. 3) and unidentified soilinhabiting nematodes present in the soil samples examined (data not shown).

Real-time PCR with SYBR green I. Twofold serial dilutions starting from 10 fourth-stage juveniles per $65 \mu$ were studied to determine the sensitivity and the detection range of the real-time PCR assay. From the dilution series, standard curves were generated with a nearly perfect negative relationship between cycle number and log number of nematodes for three sample preparations (Fig. 4). The slope ranged from -3.45 to -3.66 , and the amplification efficiency varied from 1.88 to 1.95 . Melting curve analysis and gel analysis confirmed the presence of only one specific amplicon (expected fragment length $=143 \mathrm{bp}$ ) with $T_{m}=$ $82.5^{\circ} \mathrm{C}$. These analyses did not reveal any primer-dimers that could disturb the accuracy of real-time quantification. Standard deviation in measurement of $\mathrm{Ct}$ usually ranged from 0.3 to 0.8 in intra-assay and from 0.1 to 0.8 in inter-assay; consequently, the

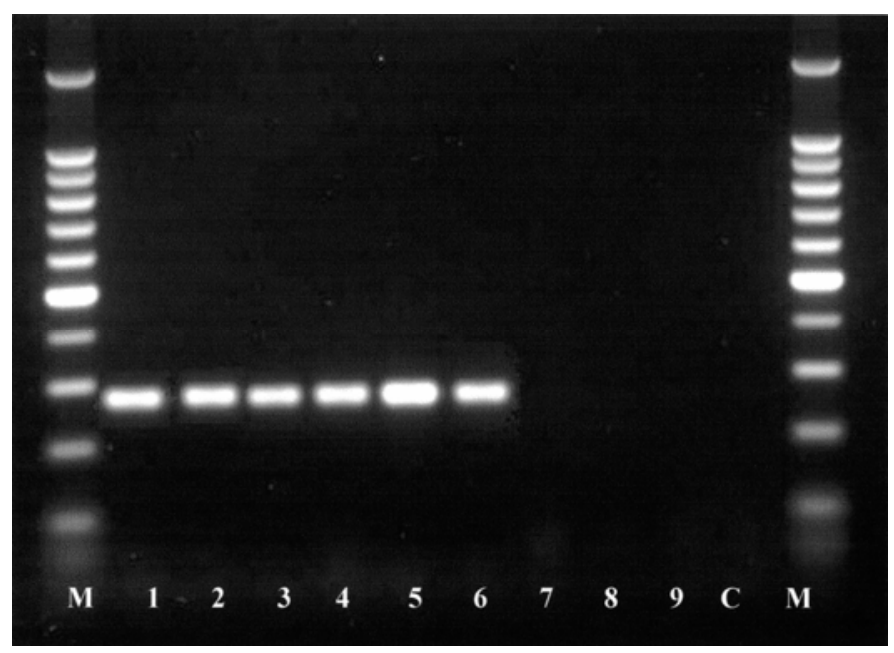

Fig. 3. Polymerase chain reaction with species specific primer for Ditylenchus dipsaci sensu stricto. Lane M, 100-kb DNA marker (Promega); 1 to 6, D. dipsaci sensu stricto populations (1, alfalfa; 2, oat; 3, garlic; 4, clover; 5, corn; and 6, Lysimachia); 7 to 8, giant race of Ditylenchus sp. B from Vicia faba, England and Syria; 9, Ditylenchus sp. G from Plantago maritima; and C, control without DNA. reproducibility of the assay was considered acceptable. The limit of detection was near 1/100 body of a fourth-stage juvenile.

To evaluate the specificity of the real-time specific primer pair, we performed real-time PCR on samples from different Ditylenchus species in Table 1. A positive result was obtained only with populations belonging to $D$. dipsaci sensu stricto.

To estimate the sensitivity and accuracy, the real-time PCR assay was applied to samples containing 1, 3, or 10 fourth-stage juveniles of $D$. dipsaci sensu stricto, or three juveniles with a background of soil-inhabiting nematodes. The assay detected target nematodes in all samples containing juveniles of Ditylenchus sensu stricto. The calculated predictive value of the real-time PCR assay varied among these samples. The lowest accuracy of quantification was revealed for some samples containing one or three specimens (Table 2). Statistical analysis did not reveal a significant difference $(P<0.05)$ in the variants with pure cultures of ditylenchid nematodes and mixed samples. Thus, a background of other soil-inhabiting nematodes in tested samples did not significantly disturb the accuracy of our assay.

\section{DISCUSSION}

Taxonomy of the $D$. dipsaci complex. Results of the present study confirm previous assumptions by Steiner (36), Sturhan $(38,39)$, Ladygina and Barabashova (23), Barabashova (1), Ladygina (22), Sturhan and Brzeski (42), and others that D. dipsaci is in fact a species complex. This complex contains several species differing in some morphometric characters, host plant range, chromosome number, and ITS-rRNA gene sequences. In our phylogenetic study (Fig. 1), the largest cluster with similar sequences included all populations from cultivated plants and populations from ornamental and some wild plants (Phlox drummondii, Digitalis lutea, Lysimachia vulgaris, Plantago lanceolata, and Veronica gentianoides). The low sequence divergence (up to $1.3 \%$ for ITS1-5.8S-ITS2 and up to $3.1 \%$ for ITS2) suggests that all these populations belong to one and the same species, which we consider here as a true $D$. dipsaci, or $D$. dipsaci sensu stricto. A population of the type-host of this species, Dipsacus fullonum, has not been available for our work. However, the results of a previous comparative RFLP-ITS study (54) of $D$. dipsaci populations from Dipsacus fullonum and six cultivated plants using 14 restriction enzymes did not reveal any differences in restriction profiles. These data suggest that there may not be any significant

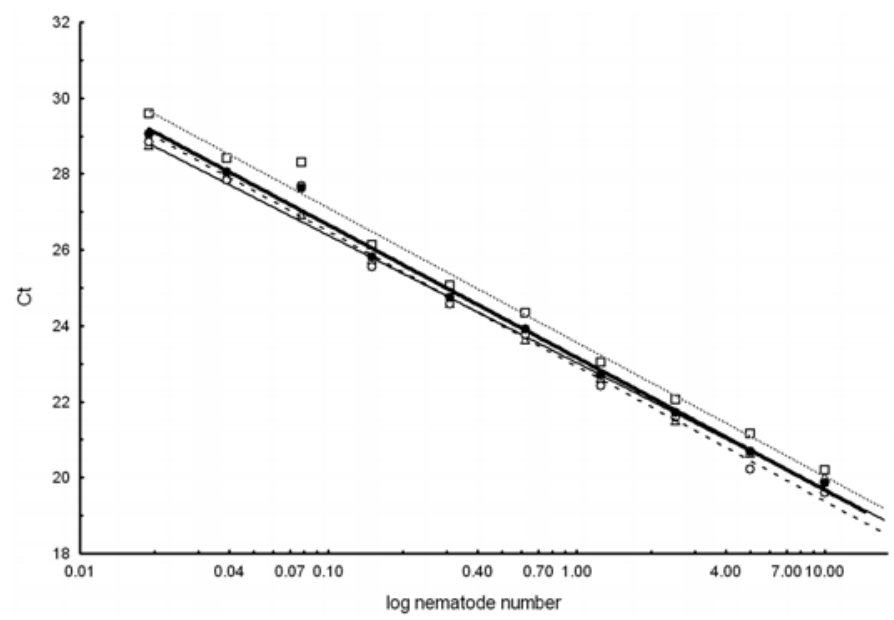

Fig. 4. Three standard curves based on three independent DNA extractions for the Ditylenchus dipsaci sensu stricto. The critical threshold $(\mathrm{Ct})$ cycle number is plotted against the log nematode number. $\square$, test $1: y=-3.61 x+23.552 ; \Delta$, test 2: $y=-3.45 x+22.966$; $\bigcirc$, test $3: y=-3.66 x+22.914$; and $\bullet$, average for three tests: $y=-3.49 x+23.169$. Correlation coefficients of three standard curves obtained by linear regression analysis are $r^{2}=0.9876,0.9989,0.9882$, and 0.9915 , respectively. 
differences in the ITS sequences between the population from the type-host and the other populations, with the exception of giant populations from Vicia faba.

Karyological studies of the $D$. dipsaci sensu stricto populations from different host plants revealed that most populations of this species have $2 n=24$ chromosomes (41). In several studies, other numbers of chromosomes were observed: $2 n=12$ chromosomes for populations from Vicia faba and Medicago sativa $(5,42)$ and $2 n=16$ chromosomes for a population from strawberry (30); however, these data require reconfirmation.

The extremely wide intraspecific variation in host preference of the stem nematode $D$. dipsaci sensu stricto has been known since the early observations by Ritzema Bos (32). However, the reliability of designating and distinguishing well-defined biological or host races in this species has often been questioned $(15,42,50)$. Previous attempts failed to separate populations of different origins or of various biological races of the stem nematode by different methods such as isoenzyme and total protein electrophoresis $(8,14)$, polyclonal (53) and monoclonal (29) antibodies, and molecular methods using PCR-ITS-RFLP (54), RAPD (9), and amplified fragment length polymorphism (AFLP) (10). Also, the present ITS data do not support the separation of populations or biological races of $D$. dipsaci sensu stricto from each other, and thus confirm the results of previous studies.

Hybridizing experiments with certain biological races, in particular with races considered rather specialized (red clover, white clover, lucerne, strawberry, phlox, narcissus, and tulip), have shown that in certain combinations only a few crossed and sterile hybrids developed, the rate of morphologically abnormal offspring was high, or that only one-sided crosses were possible but crosses failed in reciprocal combinations $(7,19,21,23,37,53)$. This genetic incompatibility and the partial reproductive isolation could indicate that $D$. dipsaci sensu stricto is presently in the state of speciation.

That speciation did occur within stem nematodes and several separate species can be distinguished within the $D$. dipsaci complex. Separate species status had also been suggested for the giant race from Vicia faba $(9,38,39)$, for the Ditylenchus populations from Plantago maritima (38-40) and populations from Hieracium (Pilosella), Sonchus, Taraxacum, Picris, and Falcaria $(1,2,20-$ 23,46). As clearly revealed by our analyses of the ITS (Fig. 1), besides the populations of the giant race from Vicia faba (Ditylenchus sp. B) and populations from Plantago maritima (Ditylenchus sp. G), the different populations from various Asteraceae hosts appear to deserve species status (Ditylenchus spp. C to F). All these species have polyploidy chromosome numbers. Populations of the giant race from Vicia faba and from Plantago maritima were shown to have $2 n=48$ to 60 and $2 n=48$ to 54 chromosomes, respectively $(38,39)$, and populations from Pilosella officinarum (= Hieracium pilosella) and Cirsium setosum had $2 n=$ 46 and $2 n=52$ chromosomes, respectively $(1,2)$. Populations from five additional Asteraceae species, which had not been included in the present study, had chromosome numbers of $2 n=$ 36 to 56 (42); therefore, the assumption appears justified that all populations from Asteraceae hosts used in the present study are also polyploid. Hybridization studies also support separate species status for these populations. Crossing experiments with populations from Vicia faba, Plantago maritima, Sonchus oleraceus, and other Asteridae hosts had revealed genetic incompatibility with diploid races of $D$. dipsaci sensu stricto $(20,38,39)$. Also, interbreeding of the polyploid giant race with a polyploid population from Plantago maritima failed (42).

Several authors have suggested a species status for the giant race from Vicia faba, which differs from normal $D$. dipsaci populations in larger body dimensions $(9,38,39)$. PCR-ITS-RFLP (54) and ITS-rDNA (44) sequence analyses also distinguish the giant race from Vicia faba from diploid species of $D$. dipsaci sensu stricto, as did RAPD and AFLP $(9,10)$. Our more complete ITS data support the results of other authors that the giant bean race is not a mere host race but should be considered a separate species.

Phylogenetic relationships and use of secondary structure of the ITS2 region of premature rRNA. All phylogenetic methods used in this study yielded the same pattern for phylogenetic relationships within the $D$. dipsaci species complex but with different statistical support for some clades. In this study, we applied Bayesian inference to analyze our ITS2 data set. This relatively new method is the only one that allows one to implement a complex model of molecular evolution, especially considering different models for stems and loops of secondary structure of rRNA molecules. Recently, this approach was applied for analyses of 18S rRNA of insects (17) and helped to resolve problems of incongruency in phylogenetic results yielded by other methods.

Although the biological role of the ITS spacers is not well understood, the utilization of the yeast model has definitely shown their importance for production of the mature rRNAs. Yeast ITS2 is the only molecule for which the secondary structure has been unambiguously resolved through a combination of chemical and enzymatic probing, minimum energy modeling, genetic experiments, and phylogenetic analyses $(49,55)$. Although ITS2 sequences exhibit a high rate of size and sequence variation during evolution of eukaryotes, the secondary structure of ITS2 exhibits several common features. ITS2 is organized around a preserved central core of secondary structure from which four helices emerge. Four domain models of the ITS2 were observed in fungi $(27,55)$, green algae (25), flowering plants (12), trematodes (26), monogeneas (28), trichostrongylids (4), Drosophila (33), and mammals (27). Using the energy minimization approach and comparative sequence analysis, we found that the secondary structure of ditylenchid ITS2 contains three domains. Three domain structure of the ITS2 has been found for several other tylenchid nematodes (S. A. Subbotin, unpublished data).

The knowledge of the RNA structure is becoming increasingly important in assisting phylogenetic analysis. Most substitution models treat changes along nucleotide sequences as independent. It has been shown in our study that the mode of evolution within helical regions of the ITS2 is via semi-compensatory mutations (i.e., $\mathrm{GC}$ to $\mathrm{GU}$ or $\mathrm{AU}$ to $\mathrm{GU}$ ); thus, the evolution of bases in structurally related position is highly dependent. The knowledge of the secondary structure allowed us to apply the more complex

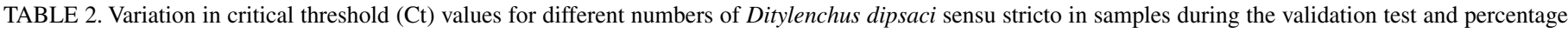
of correctly quantified samples

\begin{tabular}{|c|c|c|c|}
\hline Nematode number in sample (number of studied samples) & Observed $\mathrm{Ct} \pm \mathrm{SD}$ & Expected $\mathrm{Ct} \pm \mathrm{SD}$ & $\begin{array}{l}\text { Percentage of correctly } \\
\text { quantified samples }{ }^{\mathrm{a}}\end{array}$ \\
\hline 1 juvenile $(n=20)$ & $24.7 \pm 1.6(22.0-29.0)$ & $23.3 \pm 0.6$ & $85 \%$ \\
\hline 3 juveniles $(n=20)$ & $21.7 \pm 1.3(19.0-24.3)$ & $21.6 \pm 0.6$ & $75 \%$ \\
\hline 3 juveniles with 10 to 15 soil-inhabiting nematodes $(n=10)$ & $22.6 \pm 0.8(21.4-24.4)$ & $21.6 \pm 0.6^{\mathrm{b}}$ & $80 \%$ \\
\hline 10 juveniles $(n=10)$ & $19.5 \pm 0.5(18.9-20.8)$ & $19.6 \pm 0.6^{b}$ & $100 \%$ \\
\hline
\end{tabular}

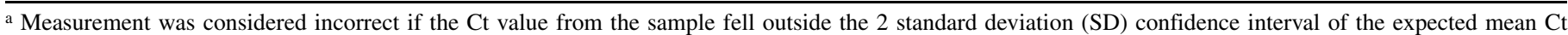
from the standard.

${ }^{\mathrm{b}}$ A $t$ test was run on data for three juveniles $+/-$ other soil-inhabiting nematodes and significant difference $(P<0.05)$ was not observed. 
model (the doublet model for stem region and the standard model for loops and bulges) using Bayesian inference, and as consequence, to generate a more realistic picture of the relationships within Ditylenchus species.

Molecular diagnostics of $\boldsymbol{D}$. dipsaci sensu stricto. The use of PCR with specific primers constitutes a major development in DNA diagnostics and enables the detection of the stem nematode in a mixture with other soil-inhabiting organisms by a single PCR test, decreasing diagnostic time and costs compared with PCRRFLP. Our PCR method allows the detection of specimens from all D. dipsaci sensu stricto populations under study. Also, Esquibet et al. (10) recently developed a multiplex PCR with sequence characterized amplified region primers for identification of the giant and the normal race of $D$. dipsaci.

In the last decade, real-time PCR-based fluorescence assay was developed as a new tool in PCR technology. This automated technique presents many advantages, including high sensitivity and DNA quantification. In addition, the results obtained can be visualized faster than gel-based PCR assays. We chose to apply the SYBR green I fluorescent dye method, because it has the virtue of being easy to use. This method can be used to detect any PCR product. To overcome the problem with the dye binding to nonspecific DNA and primer-dimers, melting curve analysis can be employed. In this study, we present evidence that real-time PCR with SYBR green I can detect and quantify fourth-stage juveniles of the stem nematode in samples. The method is straightforward, sensitive, and reproducible. Complete analysis of samples using this technique, including DNA extraction, can be performed in less than $3 \mathrm{~h}$.

The PCR quantification technique measures the number of nematodes by assuming that number of target DNA copies in the sample is proportional to the number of targeted nematodes. In order to obtain reproducible and accurate results, reactions should have an efficiency as close to $100 \%$ as possible, so that the templates double after each PCR cycle. Analysis of real-time PCR parameters in the experiments with standard curves revealed high amplification efficiency. Other factors, rather than the PCR protocol, may account for most of the heterogeneity in results of the present array.

The quantification of nematodes in samples depends on the efficiency of extraction methods and DNA purity, which should be consistent over all variants. In our study, we extracted DNA from nematodes using mechanical tissue homogenization and proteinase $\mathrm{K}$ digestion, which showed rather reproducible results. However, a lower accuracy of quantification observed in variants with low nematode numbers may be due to incomplete homogenization of nematode tissue. Recently, a new method was proposed based on the chemical lysis of nematodes in sodium hydroxide (11). Because nematodes are digested completely, the method may increase the DNA extraction efficiency, reduce the time for extraction, and exclude the most critical step of mechanical homogenization.

The present method has been developed for quantification of fourth-stage juveniles, which is the survival stage of the stem nematode in soil. Occasionally other stages such as larger adults or smaller third or second-stage juveniles can be extracted from soil samples containing infected plant materials and this could affect accuracy. Natural intra-individual variations in body size and, as consequence, variation in numbers of rDNA copies for the fourth stage may also influence accuracy.

Interestingly, the assay with a multispecies DNA mixture showed slightly higher estimation of our target component DNA. Although, statistical analysis did not reveal a significant difference in the variants with pure cultures of ditylenchid nematodes and mixed samples, influence of background of other soil-inhabiting nematodes in tested samples on accuracy of assay should be carefully studied before practical application of the method. To overcome the influence of these and other factors, including PCR inhibitors from soils, on accuracy, preparation of samples in several replicates as well as serial dilution of samples could be recommended for real-time assays.

\section{ACKNOWLEDGMENTS}

We thank J. Burr and two anonymous referees for critically reading the manuscript and offering helpful suggestions, and S. Amiri, V. N. Chizhov, F. Lamberti, P. Knuth, H. Krall, Z. Volodchenko, and V. Zinovjev for providing nematode material. M. Madani appreciates the awarding of a scholarship from the Iranian Ministry of Science, Research and Technology.

\section{LITERATURE CITED}

1. Barabashova, V. N. 1978. Karyological investigations of stem nematodes from the Ditylenchus dipsaci complex. (In Russian.) Nauchnye Doklady Vysshei Shkoly, Biologicheskie Nauki No. 5:109-114.

2. Barabashova, V. N. 1979. The karyotypes of stem nematodes of wild plants. (In Russian.) Parazitologiya 13:257-261.

3. Cannone, J. J., Subramanian, S., Schnare, M. N., Collett, J. R., D’Souza, L. M., Du, Y., Feng, B., Lin, N., Madabusi, L. V., Muller, K. M., Pande, N., Shang, Z., Yu, N., and Gutell, R. R. 2002. The comparative RNA web (CRW) site: An online database of comparative sequence and structure information for ribosomal, intron, and other RNAs. BMC Bioinformatics 3,2:1-32.

4. Chilton, N. B., Hoste, H., Newton, L. A., Beveridge, I., and Gasser, R. B. 1998. Common secondary structures for the second internal transcribed spacer pre-rRNA of two subfamilies of trichostrongylid nematodes. Int. J. Parasitol. 28:1765-1773.

5. d'Abbaddo Gallo, M., Morone de Lucia, M. R., Grimaldi de Zio, S., and Lamberti, F. 1982. Caryo-phenotype relationships in Ditylenchus dipsaci. Nematol. Mediterr. 10:39-47.

6. Eriksson, K. B. 1965. Crossing experiments with races of Ditylenchus dipsaci on callus tissue cultures. Nematologica 11:244-248.

7. Eriksson, K. B. 1974. Intraspecific variation in Ditylenchus dipsaci. 1. Compatibility tests with races. Nematologica 20:147-162.

8. Eriksson, K. B., and Granberg, J. 1969. Studies of Ditylenchus dipsaci races using electrophoresis in acrylamide gel. Nematologica 15:530-534.

9. Esquibet, M., Bekal, S., Castagnone-Sereno, P., Gauthier, J.-P., and Caubel, G. 1998. Differentiation of normal and giant Vicia faba populations of the stem nematode Ditylenchus dipsaci: Agreement between RAPD and phenotypic characteristics. Heredity 81:291-298.

10. Esquibet, M., Grenier, E., Plantard, O., Andaloussi, A., and Caubel, G. 2003. DNA polymorphism in the stem nematode Ditylenchus dipsaci: Development of diagnostic markers for normal and giant races. Genome 46:1077-1083.

11. Floyd, R., Abebe, E., Papert, A., and Blaxter, M. 2002. Molecular barcodes for soil nematode identification. Mol. Ecol. 11:839-850.

12. Hershkovitz, M. A., and Zimmer, E. A. 1996. Conservation patterns in angiosperm rDNA ITS2 sequences. Nucleic Acids Res. 24:2857-2867.

13. Huelsenbeck, J. P., and Ronquist, F. 2001. MrBayes: Bayesian inference of phylogeny. Bioinformatics 17:754-755.

14. Hussey, R. S., and Krusberg, L. R. 1971. Disc-electrophoretic patterns of enzymes and soluble proteins of Ditylenchus dipsaci and D. triformis. J. Nematol. 3:79-84.

15. Janssen, G. J. W. 1994. The relevance of races in Ditylenchus dipsaci (Kühn) Filipjev, the stem nematode. Fundam. Appl. Nematol. 17:469-473.

16. Joyce, S. A., Reid, A., Driver, F., and Curran, J. 1994. Application of polymerase chain reaction (PCR) methods to identification of entomopathogenic nematodes. Pages 178-187 in: COST 812 Biotechnology: Genetics of Entomopathogenic Nematode-Bacterium Complexes. A. M. Burnell, R.-U. Ehlers, and J. P. Masson, eds. Proc. Symp. Workshop, St. Patrick's College, Maynooth, Co. Kildare, Ireland. European Commission, DG XII, Luxembourg.

17. Kjer, K. M. 2004. Aligned 18S and insect phylogeny. Syst. Biol. 53:506514.

18. Kühn, J. 1857. Über das Vorkommen von Anguillulen in erkrankten Blüthenköpfen von Dipsacus fullonum L. Zeitschr. Wissenschaftl. Zoologie 9:129-137.

19. Ladygina, N. M. 1976. The genetic and physiological compatibility of different forms of the stem nematode. V. Cross-breeding the red clover race with other stem nematodes. (In Russian.) Parazitologiya 10:40-47.

20. Ladygina, N. M. 1978. Genetic and physiological compatibility and taxonomic position of different forms of stem nematodes. Pages 65-77 in: Fitogel'Mintologicheskie Issledovaniya. (In Russian.) Nauka, Moscow.

21. Ladygina, N. M. 1978. The genetic and physiological compatibility of different forms of stem nematodes. VI. Cross-breeding of Ditylenchus from cultivated plants and from weeds. (In Russian.) Parazitologiya 12:349-353. 
22. Ladygina, N. M. 1982. Biological races, karyotypes and hybridization. Page 69-86 in: Plant and Soil Nematodes. Genus Ditylenchus. V. G. Gubina, ed. (In Russian.) Nauka, Moscow.

23. Ladygina, N. M., and Barabashova, V. N. 1976. The genetic and physiological compatibility and the karyotypes of stem nematodes. (In Russian.) Parazitologiya 10:449-456.

24. Leal-Bertioli, S. C. M., Tenente, R. C. V., and Bertiolo, D. J. 2000. ITS sequence of populations of the plant parasitic nematode Ditylenchus dipsaci. Nematol. Brasil. 24:83-85.

25. Mai, J. C., and Coleman, A. W. 1997. The internal transcribed spacer 2 exhibits a common secondary structure in green algae and flowering plants. J. Mol. Evol. 44:258-271.

26. Michot, B., Després, L., Bonhomme, F., and Bachellerie, J.-P. 1993. Conserved secondary structure in the ITS2 of trematode pre-rRNA. FEBS Lett. 316:247-252.

27. Michot, B., Joseph, N., Mazan, S., and Bachellerie, J. P. 1999. Evolutionary conserved structural features in the ITS2 of mammalian prerRNAs and potential interaction with the snoRNA U8 detected by comparative analysis of new mouse sequences. Nucleic Acids Res. 27:22712282.

28. Morgan, J. A. T., and Blair, D. 1998. Trematode and monogenean rRNA ITS2 secondary structure support a four-domain model. J. Mol. Evol. 47:406-419.

29. Palmer, H. M., Atkinson, H. J., and Perry, R. N. 1992. Monoclonal antibodies (Mabs) specific to surface expressed antigens of Ditylenchus dipsaci. Fundam. Appl. Nematol. 15:511-515.

30. Paramonov, A. A. 1962. Principles in Phytonematology. Vol. 1. (In Russian.) Nauka, Moscow.

31. Powers, T. O., Szalanski, A. L., Mullin, P. G., Harris, T. S., Bertozzi, T., and Griesbach, J. A. 2001. Identification of seed gall nematodes of agronomic and regulator concern with PCR-RFLP of ITS1. J. Nematol. 33:191-194.

32. Ritzema Bos, J. 1888. L'anguillule de la tige (Tylenchus devastatrix Kühn) et les maladies des plantes dues à ce nématode. Arch. Mus. Teyler 2:161-348.

33. Schlötterer, C., Hauser, M.-T., von Haeseler, A., and Tautz, D. 1994. Comparative evolutionary analysis of rDNA ITS regions in Drosophila. Mol. Biol. Evol. 11:513-522.

34. Seinhorst, J. W. 1956. Population studies on stem nematodes (Ditylenchus dipsaci). Nematologica 1:159-164.

35. Shubina, L. V. 1989. About biotypes of Ditylenchus dipsaci (Nematoda: Anguinidae). Pages 203-207 in: Problems of Plant Nematology. M. D. Sonin, ed. (In Russian.) Nauka, Moscow.

36. Steiner, G. 1956. The problem of the taxon in the nematode genus Ditylenchus and its agricultural implications. Pages 377-379 in: Proc. XIVth Int. Congress Zoology. Copenhagen 1953, Copenhagen.

37. Sturhan, D. 1964. Kreuzungsversuche mit biologischen Rassen des Stengelälchens (Ditylenchus dipsaci). Nematologica 10:328-334.

38. Sturhan, D. 1969. Das Rassenproblem bei Ditylenchus dipsaci. Mitt. Biol. Bundesanst. Land-Forstwirtsch. 136:87-98.

39. Sturhan, D. 1970. Ditylenchus dipsaci-doch ein Artenkomplex? Nematologica 10:327-328.

40. Sturhan, D. 1971. Biological races. Pages 51-71 in: Plant Parasitic
Nematodes. Vol. 2. B. M. Zuckerman, W. F. Mai, and R. A. Rohde, eds. Academic Press, New York.

41. Sturhan, D. 1983. The use of the subspecies and the superspecies categories in nematode taxonomy. Pages 41-53 in: Concepts in Nematode Systematics. A. R. Stone, H. M. Platt, and L. F. Khalil, eds. Academic Press, London and New York.

42. Sturhan, D., and Brzeski, M. W. 1991. Stem and bulb nematodes, Ditylenchus spp. Pages 423-465 in: Manual of Agricultural Nematology. W. R. Nickle, ed. Marcel Dekker, New York.

43. Subbotin, S. A., Krall, E. L., Riley, I. T., Chizhov, V. N., Staelens, A., De Loose, M., and Moens, M. 2004. Evolution of the gall-forming plant parasitic nematodes (Tylenchida: Anguinidae) and their relationships with hosts as inferred from internal transcribed spacer sequences of nuclear ribosomal DNA. Mol. Phylogen. Evol. 30:226-235.

44. Subbotin, S. A., Madani, M., Krall, E. L., Sturhan, D., and Moens, M. 2003. Identification and phylogenetic relationships within the stem nematode Ditylenchus dipsaci complex (Tylenchida: Angunidae) as inferred from analysis of the ITS-rDNA sequences. J. Nematol. 35:365.

45. Subbotin, S. A., Waeyenberge, L., and Moens, M. 2000. Identification of cyst forming nematodes of the genus Heterodera (Nematoda: Heteroderidae) based on the ribosomal DNA-RFLPs. Nematology 2:153-164.

46. Sumenkova, N. I. 1982. Taxonomic review of nematodes of the genus Ditylenchus. Pages 5-69 in: Plant and Soil Nematodes. Genus Ditylenchus. V. G. Gubina, ed. (In Russian.) Izdatel'stvo Nauka, Moscow.

47. Swofford, D. L. 1998. PAUP*. Phylogenetic analysis using parsimony and other methods. Version 4. Sinauer Associates, Sunderland, MA.

48. Thompson, J. D., Gibson, T. J., Plewniak, F., Jeanmougin, F., and Higgins, D. G. 1997. The ClustalX windows interface: Flexible strategies for multiple sequence alignment aided by quality analysis tools. Nucleic Acids Res. 24:4876-4882.

49. Van der Sande, C. A., Kwa, M. R., van Nues, R. W., van Heerikhuizen, H., Raué, H. A., and Planta, R. J. 1992. Functional analysis of internal transcribed spacer 2 of Saccharomyces cerevisiae ribosomal DNA. J. Mol. Biol. 223:899-910.

50. Viglierchio, D. R. 1971. Race genesis in Ditylenchus dipsaci. Nematologica 17:386-392.

51. Vrain, T. C., Wakarchuk, D. A., Levesque, A. C., and Hamilton, R. I. 1992. Intraspecific rDNA restriction fragment length polymorphisms in the Xiphinema americanum group. Fundam. Appl. Nematol. 15:563-573.

52. Webster, J. M. 1967. The significance of biological races of Ditylenchus dipsaci and their hybrids. Ann. Appl. Biol. 59:77-83.

53. Webster, J. M., and Hooper, D. J. 1968. Serological and morphological studies on the inter- and intraspecific differences of the plant-parasitic nematodes Heterodera and Ditylenchus. Parasitology 58:879-891.

54. Wendt, K. R., Vrain, T. C., and Webster, J. M. 1993. Separation of three species of Ditylenchus and some host races of $D$. dipsaci by restriction fragment length polymorphism. J. Nematol. 25:555-563.

55. Yeh, L. C. C., and Lee, J. C. 1990. Structural analysis of the internal transcribed spacer 2 of the precursor ribosomal RNA from Saccharomyces cerevisiae. J. Mol. Biol. 211:699-712.

56. Zuker, M. 2003. Mfold web server for nucleic acid folding and hybridization prediction. Nucleic Acids Res. 31:3406-3415. 